\title{
DISCRIMINATING AMONG \\ ALTERNATIVE THEORIES OF \\ THE MULTINATIONAL ENTERPRISE
}

James R. Markusen

Keith E. Maskus

Working Paper 7164

http://www.nber.org/papers/w7164

NATIONAL BUREAU OF ECONOMIC RESEARCH

1050 Massachusetts Avenue

Cambridge, MA 02138

June 1999

The authors thank Rebecca Neumann for capable and timely research assistance. All opinions expressed are those of the authors and not those of the National Bureau of Economic Research.

(C) 1999 by James R. Markusen and Keith E. Maskus. All rights reserved. Short sections of text, not to exceed two paragraphs, may be quoted without explicit permission provided that full credit, including (C) notice, is given to the source. 
Discriminating Among Alternative Theories

of the Multinational Enterprise

James R. Markusen and Keith E. Maskus

NBER Working Paper No. 7164

June 1999

JEL No. F13, F23

\section{ABSTRACT}

Recent theoretical developments have incorporated endogenous multinational firms into the general-equilibrium model of trade. One simple taxonomy separates the theory into "vertical" models in which firms geographically separate activities by stages of production and "horizontal" models of multi-plant firms which duplicate roughly the same activities in many countries. We refer to a hybrid of these two as the "knowledge capital model". In this paper, we nest these three models within an unrestricted model. Econometric tests give strong support to the horizontal model and overwhelming reject the vertical model.

James R. Markusen

Department of Economics

University of Colorado

Boulder, CO 80309-0256

and NBER

james.markusen@colorado.edu
Keith E. Maskus

Department of Economics

University of Colorado

Boulder, CO 80309-0256

keith.maskus@colorado.edu 


\section{1. $\quad$ Introduction}

While much of the industrial organization approach to trade makes little reference to multinational firms, a number of papers published over the last 15 years have been successful in incorporating endogenous multinational firms into general-equilibrium trade models. As a consequence, we now have a reasonably well-developed set of theories which have implications about the relationship between MNE activity and country characteristics such as size and relative endowments.

One basic distinction in the theory is between "vertical" and "horizontal" firms. Vertical MNEs are firms that geographically fragment production into stages, typically on the basic of factor intensities, locating skilled-labor intensive activities in skilled-labor-abundant countries and so forth. Treatments of vertical investments include Helpman (1984), and Helpman and Krugman (1985). Horizontal MNEs are multi-plant firms that replicate roughly the same activities in many locations. Models of horizontal firms include Markusen (1984), Horstmann and Markusen (1987, 1992), and Markusen and Venables (1997, 1998).

These two strains of literature have been relative disjoint, in large part due to technical difficulties. The early papers by Helpman and Helpman-Krugman relied on zero trade costs to produce analytical solutions. But under this assumption, there is no role for horizontal multi-plant firms given plant-level scale economies. Papers in the Horstmann-Markusen-Venables tradition typically assumed that there is only one factor used in the MNEs sector, or that different activities (e.g., headquarters and plant) use factors in the same proportion. But under these assumptions, there is little motivation for fragmenting production by stages.

More recently, there have been several attempts to integrate these models, allowing firms the 
options of multiple plants or geographically separating a headquarters and single plant (Markusen, 1997). This has been referred to as the "knowledge-capital model" insofar as it is motivated by assuming that knowledge is geographically mobile and a joint input to multiple production facilities.

There have been several models which estimate these models. Results in Brainard (1997, 1993) give support to the horizontal model, and little support to the vertical model. Several papers by Ekholm (1995a, 1997, 1998a,b) give indirect support to the knowledge-capital model. More direct tests in Carr, Markusen, and Maskus (1998), and Markusen and Maskus (1999), give good support to the knowledge-capital model.

A difficulty with these estimations and indeed a chronic difficulty in empirical work more generally is that there is no explicit alternative hypothesis (H1) to the model being estimated. Indeed, authors are generally cautious about referring to "testing" the theory. The purpose of this paper is to attempt just such a test of the three models just mentioned: the knowledge-capital model (henceforth KK), the horizontal model (henceforth HOR) and the vertical model (henceforth VER). We will develop the basic theory briefly, and note how each model offers predictions about foreign affiliate production of multinational firms as a function of characteristics of both the parent and the host country. The three models are then nested within an unrestricted model and estimated.

Results of this exercise provide strong support to the horizontal model (HOR), and decisively reject the vertical model (VER). The KK model performs much better than the VER model, but its restrictions are rejected and one coefficient has the wrong sign. The formal results thus accord well with casual empiricism. The overwhelming proportion of world direct investment is from highincome developed countries to other similar high-income developed countries. This suggests horizontal investment is much more important in the world economy than vertical investment, at least 
vertical investments motivated by factor-endowment differences.

2. Theory

Consider the following simple two-good, two-factor, two-country general-equilibrium model.

(1) There are two homogeneous goods, $\mathrm{X}$ and $\mathrm{Y}$

(2) There are two factors, skilled (S) and unskilled labor (L), immobile between countries

(3) There are two countries, $h$ and $f$

(4) $\mathrm{Y} \quad-\quad$ constant returns, perfect competition, L intensive

(5) $X \quad-\quad$ (a) increasing returns to scale

(b) S intensive

(c) firms are Cournot competitors

(4) X production requires a "headquarters" (fixed cost) activity and a production activity

(5) an X firm may have one or two plants

(6) there is free entry and exit within an X "firm type" and among firm types

(a) firm type-N: single-plant national firms with their headquarters and plant in the same country

(b) firm type-H: two-plant horizontal firms with their headquarters in one country and plants in both countries

(c) firm type-V: single plant vertical firms with their headquarters and plant in different countries

(7) transport costs between markets use L

(8) markets are segmented

(9) Options menu for the $\mathrm{X}$ sector

(a) there are firm-level as well as plant-level scale economies

(b) single plant firms may geographically separate plant and headquarters

(c) headquarters and plants have different factor intensities 
From the options menu, we can construct our three different models based on alterative assumptions. These are as follows:

\section{$\underline{\text { KK model }}$}

(KK1) There are firm-level as well as plant-level scale economies

(KK2) A single-plant firm may geographically separate headquarters and plant

(KK3) Firm-level fixed costs are skilled-labor intensive relative to plant-level fixed costs and the marginal costs of production.

$\underline{\text { VER model }}$

(VER1) There are no firm-level scale economies

(KK2) A single-plant firm may geographically separate headquarters and plant

(KK3) Firm-level fixed costs are skilled-labor intensive relative to plant-level fixed costs and the marginal costs of production.

\section{$\underline{\text { HOR model }}$}

(KK1) There are firm-level as well as plant-level scale economies

(HOR2) A single-plant firm may not geographically separate headquarters and plant

(HOR3) Firm-level fixed costs, plant-level fixed costs and the marginal costs of production all use factors in the same proportion.

While the VER and HOR models are fairly well know, that might not be the case with KK so perhaps a few more comments are in order. The KK model as laid out in Markusen (1997) and Carr, Markusen, and Maskus (1998) makes three principal assumptions.

(A) Transportability: the services of knowledge-based assets are easily supplied to geographically separate facilities.

(B) Factor Intensity: Knowledge capital is skilled-labor intensive relative to final production. 
(C) Jointness: the services of knowledge-based assets are (at least partially) joint ("public") inputs into geographically separate production facilities.

Properties (A) and (B) create a motive for the vertical fragmentation of production. A firm's headquarters should be located in a country where skilled labor is cheap while a single production plant might be located in the other country. Property (C) implies firm-level scale economies and creates a motive for horizontal investments which replicate the same products or services in different locations.

What then does theory tell us about the relationship between multinational activity and country characteristics? In the VER model with no firm-level scale economies and no motive for horizontal firms, multinational activity is driven entirely by differences in factor endowments. Type-V firms will be important when countries differ in relative endowments. To make the point very directly, multinationals will never exist between identical countries.

In the HOR model, we get more or less the opposite result. MNEs will be most important between similar countries, provided of course that there are positive trade costs. MNEs will be less important as the countries differ in size or in relative endowments. The intuition here is that when countries differ significantly, one will be a "favored" country as a headquarters for single-plant national firms, either because of a large domestic market (a type- $\mathrm{H}$ firm must locate costly capacity in a small market) and/or factor-price differences.

In the KK model, MNEs can exist both when the countries are similar (type-H firms), or different in relative endowment, particularly if the skilled-labor-abundant country is small. In the latter case, the headquarters should be located in the skilled-labor-abundant country and the plant in the large, skilled-labor-scarce country both for a factor-price motive and for a market-size motive. 
These results are summarized as follows.

\section{$\underline{\text { KK model }}$}

(1) Both type-H and type-V multinationals can exist.

(2) Multinational are important when countries are similar in size and in relative endowments, and trade costs are moderate to high (type-H multinationals).

(3) Multinationals are important when countries differ in relative endowments, particularly if the skilled-labor abundant country is small.

\section{$\underline{\text { VER model }}$}

(1) Only type-V multinationals can exist.

(2) Multinationals are important when countries differ in relative endowments.

(3) Multinationals do not arise between identical countries.

\section{$\underline{\text { HOR model }}$}

(1) Only type-H multinationals can exist.

(2) Multinational are important when countries are similar in size and in relative endowments, and trade costs are moderate to high.

Figures $1 \mathrm{a}, 1 \mathrm{~b}$, and $1 \mathrm{c}$ depict simulation results for the three models. ${ }^{1}$ The diagrams are the world Edgeworth box, with the world endowment of skilled labor on one axis of the base and unskilled labor on the other. The vertical axis measures the real volume of affiliate production; that is, the production by plants in country f of firms headquartered in country $h$ (type $\mathrm{H}_{h}$ or $\mathrm{V}_{\mathrm{h}}$ ) and vice

\footnotetext{
${ }^{1}$ These results are derived from a computer simulation model develop in Markusen (1997), following the earlier work of Markusen and Venables $(1997,1998)$ with four firm types (no type-V firms). It uses a complementarity algorithm developed and implemented by Rutherford (1995a,b). Marginal-revenue, marginalcost inequalities have outputs per firm as complementary variables, and markup-revenues, fixed-costs inequalities have the numbers of firms active in equilibrium as complementary variables.
} 
versa. This will prove to be the most useful representation of theory, since the data give us numbers on affiliate production and sales, but not on the numbers of firms (and certain not by "type"). The endowment of country h is measured from the near, southwest corner (SW) and the endowment of country f from the far, northeast (NE) corner.

Relative to Figure 1a, Figure 1b eliminates firm-level scale economies. Relative to Figure 1a, Figure 1c eliminates type-V firms, requires that $\mathrm{S}$ and $\mathrm{L}$ are used in the same proportion in fixed and variables costs, and that there are significant skilled-labor requirements in the host country.

The KK and HOR models both show an inverted U-shaped curve along the SW-NE diagonal. Type-H MNEs exist between countries with identical relative endowments, and affiliate production is maximized when the countries are identical. (When the countries are very different in size, singleplant type-N firms located in the large country will have the advantage as noted above.) In the VER model, there is essentially no MNE activity along the SW-NE diagonal, and no role for country size and size difference independent of relative endowment differences.

Along the NW-SE diagonal (countries differ in relative endowments), it is the KK and VER models that are more similar to each other than to the HOR model. In the latter model, type-H firms become disadvantaged as they have to hire costly skilled labor in the skilled-labor scarce country. Vertical firms on the other hand are encouraged to enter in both the KK and the VER model as relative endowment differences increase.

Yet there is another interesting difference between the VER and KK models. We see in the VER model a relatively uniform relationship between endowment differences and total affiliate activity, with little dependence on country size. In the KK model, there is a interaction effect between country size differences and relative endowment differences. Affiliate activity is maximized when one 
country is relatively small and skilled-labor abundant. In such a situation, most all $\mathrm{X}$ production is by type- $\mathrm{V}$ firms, and all $\mathrm{X}$ produced by a type- $\mathrm{V}$ firm is affiliate production by definition. In the $\mathrm{KK}$ model, when countries differ significantly in relative endowments but are similar in size, many of the multinational firms active in equilibrium are type- $\mathrm{H}$ firms, and only the non-headquarters-country production of these firms counts as affiliate production. So, for example, if country $h$ is large and skilled-labor abundant, then type- $\mathrm{H}_{\mathrm{h}}$ firms might be important but most of their output is domestic production in country h, not affiliate production in country f. Thus affiliate production is less in this region in the KK model than in the VER model.

Figure 2 shows the results in one direction only: production in country $\mathrm{f}$ by affiliates of firms headquartered in country $\mathrm{h}$. The reason to look at the one-way results is that it greatly increases the degrees of freedom in the econometric estimation to treat h-to-f and f-to-h as separate observations. There are clearly non-linearities and non-monotonicities in these results. But some clear ideas emerge. First, in the KK model there is a role for total income and size difference independent of relative endowment differences (i.e., the SW-NE diagonal), but there is also a role for relative endowment differences and an interaction between relative endowment differences and size differences. Outward affiliate activity of country $h$ headquartered firms in country $f$ is highest when $\mathrm{h}$ is both small and skilled-labor abundant.

Second, the VER model gives no role for total income and the size difference between the countries independent of relative endowment differences. If we were to increase the density of endowments (income) in the Edgeworth box in Figure 2b, the "wing" on the left would rotate upwards (becomes steeper) with affiliate activity remaining zero on the SW-NE diagonal. Thus the model predicts that affiliate activity increases with total income but only in proportion to relative 
endowment differences. Size difference between the countries plays no role (except at very extreme values).

Third, the HOR model gives the clearest role for total income and country-size similarity. While the maximum point of affiliate activity over the Edgeworth box is not at the center (it occurs when country h is slightly skilled-labor abundant and slightly smaller than country f), affiliate activity falls off from the maximum as the country gets either more/less skilled-labor abundant or bigger/smaller.

To summarize the simulation results in Figures 1 and 2, the KK and HOR models predict an important role for total two-country income and difference in income independent of relative endowment differences, while the VER model predicts no such independent role. The KK and VER models predict a role for relative endowment differences with country h's outward affiliate activity increasing in its skilled-labor abundance. The KK model predicts a positive interaction between skilled-labor abundance and a small size (or rather a negative interaction between skilled-labor abundance and size) while the other two models do not. 


\section{Data Sources and Variable Construction}

To implement the model, we define the following variables, which are listed in Table 1, and discuss their construction. The data form a panel of cross-country observations over the period 198694. First, we take sales volume of non-bank manufacturing affiliates in each country to indicate production activity. The U.S. Department of Commerce provides annual data on sales of foreign affiliates of American parent firms and on sales of U.S. affiliates of foreign parent firms. Thus, for each year the United States serves as both the headquarters country for its firms producing abroad and the affiliate country for foreign firms producing there. There are 36 countries in addition to the US for which we have at least one year of complete data. Annual sales values abroad are converted into millions of 1990 U.S. dollars using an exchange-rate adjusted local wholesale price index, with exchange rates and price indexes taken from the International Financial Statistics of the International Monetary Fund.

Real gross domestic product is measured in billions of 1990 U.S. dollars for each country. For this purpose, annual real GDP figures in local currencies were converted into dollars using the market exchange rate. These data are also from the IFS.

Skilled labor abundance is defined as the sum of occupational categories 0/1 (professional, technical, and kindred workers) and 2 (administrative workers) in employment in each country, divided by total employment. Variables $\mathrm{SK}_{\mathrm{h}}$ and $\mathrm{SK}_{\mathrm{j}}$ thus have a potential range of 0 (very skilledlabor scarce) to 1 (very skilled-labor abundant). These figures are compiled from annual surveys reported in the Yearbook of Labor Statistics published by the International Labor Organization. In cases where some annual figures were missing, the skilled-labor ratios were taken to equal the period averages for each country. The variable SKDIFF is then simply the difference between the relative 
skill endowment of the parent country and that of the affiliate country. Our convention will be that country $i$ is the parent country and country $j$ is the host country, so SKDIFF $=\mathrm{SK}_{\mathrm{i}}-\mathrm{SK}_{\mathrm{j}}$, is positive if the parent country is skilled-labor abundant relative to the host.

The cost of investing in the affiliate country is a simple average of several indexes of impediments to investment throughout the period, reported in the World Competitiveness Report of the World Economic Forum. ${ }^{2}$ The indexes include restrictions on ability to acquire control in a domestic company, limitations on the ability to employ foreign skilled labor, restraints on negotiating joint ventures, strict controls on hiring and firing practices, market dominance by a small number of enterprises, an absence of fair administration of justice, difficulties in acquiring local bank credit, restrictions on access to local and foreign capital markets, and inadequate protection of intellectual property. These indexes are computed on a scale from 0 to 100 , with a higher number indicating higher investment costs. A trade cost index is taken from the same source and is defined as a measure of national protectionism, or efforts to prevent importation of competitive products. It also runs from 0 to 100 , with 100 being the highest trade costs. All of these indexes are based on extensive surveys of multinational enterprises.

\footnotetext{
${ }^{2}$ Some of these data were kindly provided by staff of the United States International Trade Commission.
} 


\section{Estimation}

Table 1 gives variable definitions and predicted signs for the three models. The horizontal line in Figure 1 divides the variables of interest in the theory (above the line) from a set of common control variables which are expected to have the same signs in all equations (below the line).

Variable definitions are given at the bottom of Table 1. The first two variables, SUMGDP and GDPDIFSQ capture the inverted U-shaped relationship along the SW-NE diagonal of the Edgeworth box in Figure 2. SUMGDP is predicted to be positive and GDPDIFSQ negative for the KK and HOR models, but zero in the VER model. As noted earlier, economic size and size differences have no role in the VER model independent of factor-endowment differences.

The dummy variables D1 and D2 are designed to capture the results of Figure 2 that predictions depend very much on whether or not the parent country is the skilled-labor abundant or scarce country. Variable D1 is non-zero if the parent is skilled-labor scarce and D2 is non-zero if the parent is skilled-labor abundant relative to the host.

The complicated variable D2*SKDGDPD is designed to capture the interaction between being skilled-labor abundant and small that we discussed in connection with the KK model. This variable is predicted to have a negative sign in the KK model (i.e., being small and skilled-labor abundant increases outward investment), but be zero in the other two models.

$\mathrm{D} 2 *$ SKDSUMG is an interaction term between factor abundance and the total size of the "world" economy. This term is positive if the parent is skilled-labor abundant, and zero otherwise. This is the only "core variable" in the VER model, Figure 2b. For a given SUMGDP, outward investment is increasing in the parent country's skilled-labor abundance, and for a given SKDIFF, outward investment is increasing in the total GDP. 
D1*SKDSUMG is positive if the parent country is skilled-labor scarce. This term is hypothesized to be zero in the KK and VER models: there is no outward activity to the SE of the SW-NE diagonal of the factor box in the VER model (Figure 2b) and only a limited region where this occurs in the KK model (Figure 2a). This variable is however hypothesized to be negative in the HOR model (Figure 2c). Outward investment falls as the parent becomes skilled-labor scarce, but outward investment continues well past the point where the parent first becomes skilled-labor scarce (crossing below the SW-NE diagonal.

The first control variable (below the line in Table 1) is distance. Theory does not give a clear prediction as to its sign, since distance increases the costs of both trade (suggesting a substitution toward investment) but also investment. The second variable is the host-country's investment cost index as discussed in the previous section; since higher numbers indicate higher costs, this variable is predicted to be negative in all three regressions. TCJ is the host-country's trade cost index and this is expected to be positive, higher host-country trade costs encouraging inward investment. TCI is the parent-country's trade cost index and this is expected to be negative: it raises the costs of shipping goods back to the parent from a branch plant, although this should not be important in the case of outward horizontal investment. 


\section{5. $\quad$ Results}

Tables 2-5 present estimation results. In all cases, the dependent variable is production in country $\mathrm{j}$ by affiliates of country i parents. Variables listed as zeros in Table 1 are omitted from the regressions. A unrestricted regression (UNREST) includes all variables.

Tables 2 and 3 use only distance among the control variables. Table 2 is a weighted-leastsquares estimation using a Park-Glejser technique with 509 observations. There are a number of missing observations for the dependent variable, and on inspection these involve parent countries that are small and poor. So a reasonable assumption is that these missing values are in fact zeros. Table 3 enters these observations with a zero for affiliate production and estimates a Tobit equation on 722 observations.

Results in Tables 2 and 3 give strong support to the HOR model. The restriction on this model cannot be rejected by the F-test, and all coefficients have the right sign. The KK model can be rejected and in addition two coefficients (D2SKDGDPD, D2SKDSUMG) have the wrong sign in Table 2 and one has the wrong sign in Table 3 (D2SKDGDPD) and the other is insignificant (D2SKDSUMG).

The VER model does poorly, and in Table 2 the crucial variable D2SKDSUMG has the wrong sign. All of the influence of total two-country income is picked up in the intercept, which is large and positive, reversing the result in the other regressions. This coefficient has the right sign in the Tobit regression in Table 3 but again most of influence of size is picked up in the intercept. The restrictions that economic size and size difference plays no role in explaining multinational activity is strongly rejected.

Tables 4 and 5 give results for WLS and Tobit regressions using all the control variables. 
INVCJ is always significant and has the right sign. TCJ and TCI always have the right signs as well, although TCI has weak significance in the WLS regressions while TCJ has weak significance in the Tobit regressions.

Results in Tables 4 and 5 are consistent with those in Tables 2 and 3. HOR gets strong support in the WLS regressions in terms of signs, significance, and F-test. The restriction in HOR is "marginally" rejected in the Tobit regression, but all variables in HOR have the right sign while they do not in the KK regression.

The coefficient on D2SKDSUMG has the right sign in the VER regressions in Tables 4 and 5 , but the restrictions of the model are rejected. Note again the reversal in the sign of the intercept term in the VER regression suggesting that the independent influence of income is being absorbed into the intercept. 


\section{6. $\quad \underline{\text { Summary }}$}

The econometric results give strong support to the HOR model, and strongly reject the VER model. The coefficient estimates in the HOR model have the right signs and high statistical significance. An F-test cannot reject the HOR model's restrictions. These results tell us what researchers have long believed from casual empiricism: direct investment is most important between countries that are similar both in size and in relative endowments. It is the "hill" of Figures 1c and $2 c$ rather than the "valley" of Figures $1 b$ and $2 b$ that best describes the world. The VER model clearly should not be taken seriously as a description of the world.

The weak performance of the KK model is somewhat troubling given strong support it receives in Carr, Markusen, and Maskus (1998). Here, there does not seem to be a strong positive roles for skilled-labor abundance and the interaction between skilled-labor abundance and size found in CMM. The data are the same in the two papers, but the estimating equation is different. In CMM, the authors used their "ideal" regression equation to estimate the model, without considering an explicit alternative model. In particular, SKDIFF was used as a variable by itself and not interacted with SUMGDP. All the central coefficients had the right sign and were highly significant indicating an important role for skilled-labor abundance. In the present paper, some compromises to the "ideal" regression equation is made in order to nest the models, so as to provide a more meaningful test. ${ }^{3}$

Possibly more relevant, the effect of an increase in SKDIFF is complicated because SKDIFF appears in two regressors in the KK model. Using the mean values of GDPDIFF and SUMGDP

\footnotetext{
${ }^{3}$ If the effect of increased total income is to "lift up" the whole surface in Figure 1a (i.e., the effect of an increase in SUMGDP does not depend on SKDIFF), then the specification in CMM is preferred for estimating the KK model over the present formulation. But it is clear that SKDIFF and GDPDIFF should be interacted for the VER model (the effect of an increase in SUMGDP is proportional to SKDIFF), so we use that variable here for the KK model as well.
} 
(which vary with the number of observations), partial derivatives of the four equations for the KK model with respect to SKDIFF are positive for the two Tobit regressions, but negative for the two WLS regressions. For US outward investments (where GDPDIFF is large and positive), an increase in SKDIFF always increases outward affiliate production. Thus the results on the KK model are not as clear as they seem from looking at individual coefficients alone and a positive role for SKDIFF is not rejected here. The interested reader is referred to CMM for a more detailed treatment of the KK model. $^{4}$

We concluded by noting that the results emphasize the importance of formally considering an alternative hypothesis. If the VER model were estimated here alone, a researcher could conclude that the model gets good support, except in WLS regression with only DIST as a control where D2SKDSUMG has the wrong sign (Table 2). Yet that "good support" quickly evaporates when we look at the alternative HOR model.

\footnotetext{
${ }^{4}$ Also, Markusen and Maskus (1999) find support for the KK model by breaking down affiliate production into that which is sold in the host country and that portion which is exported back to the parent country.
} 


\section{REFERENCES}

Brainard, S. Lael (1993), "An Empirical Assessment of the Factor Proportions Explanation of Multinationals Sales", NBER Working Paper No. 4580.

Brainard, S. Lael (1997), "An Empirical Assessment of the Proximity-Concentration Tradeoff between Multinational Sales and Trade", American Economic Review 87, 520-544.

Braunerhjelm, Pontus and Karolina Ekholm (editors) (1998), The Geography of Multinational Firms. Boston: Kluwer Academic Publishers.

Carr, David, James R. Markusen and Keith E. Maskus (1998), "Estimating the Knowledge-Capital Model of the Multinational Enterprise", NBER working paper 6773.

Caves, Richard E. (1996), Multinational Enterprise and Economic Analysis. London: Cambridge University Press, second edition.

Ekhlom, Karolina (1995), Multinational Production and Trade in Technological Knowledge, Lund Economic Studies, number 58.

Ekholm, Karolina (1997), "Factor Endowments and the Pattern of Affiliate Production by Multinational Enterprises", CREDIT working paper no. 97/19, University of Nottingham.

Ekholm, Karolina (1998a), "Headquarter Services and Revealed Factor Abundance", Review of International Economics 6, 545-553.

Ekholm, Karolina (1998b), "Proximity Advantages, Scale Economies, and the Location of Production", in Braunerhjelm and Ekholm (editors), The Geography of Multinational Firms. Boston: Kluwer Academic Publishers. 1998.

Helpman, Elhanan (1984), "A Simple Theory of Trade with Multinational Corporations", $\underline{\text { Journal of }}$ Political Economy 92, 451-471.

Helpman, Elhanan and Paul Krugman (1985), Trade and Market Structure, Cambridge: MIT Press.

Horstmann, Ignatius J. and James R. Markusen (1987), "Strategic Investments and the Development of Multinationals," International Economic Review 28, 109-121.

Horstmann, Ignatius J. and James R. Markusen (1992), "Endogenous Market Structures in International Trade," Journal of International Economics 32, 109-129.

Markusen, James R. (1984), "Multinationals, Multi-Plant Economies, and the Gains from Trade", Journal of International Economics 16, 205-226. 
Markusen, James R.(1995), "The Boundaries of Multinational Firms and the Theory of International Trade", Journal of Economic Perspectives 9, 169-189.

Markusen, James R. (1997), "Trade versus Investment Liberalization", NBER working paper 6231.

Markusen, James R. and Anthony J. Venables (1997), "The Role of Multinational Firms in the WageGap Debate", Review of International Economics 5, 435-451.

Markusen, James R. and Anthony J. Venables (1998), "Multinational Firms and the New Trade Theory", Journal of International Economics 46, 183-203.

Markusen, James R. and Keith E. Maskus (1999), "Multinational Firms: Reconciling Theory and Evidence", University of Colorado working paper.

Rutherford, Thomas F. (1995a), "Applied General-Equilibrium Modelling with MPS/GE as a GAMS Subsystem".

Rutherford, Thomas F. (1995b), "Extensions of GAMS for Complementarity Problems Arising in Applied Economics", Journal of Economic Dynamics and Control. 


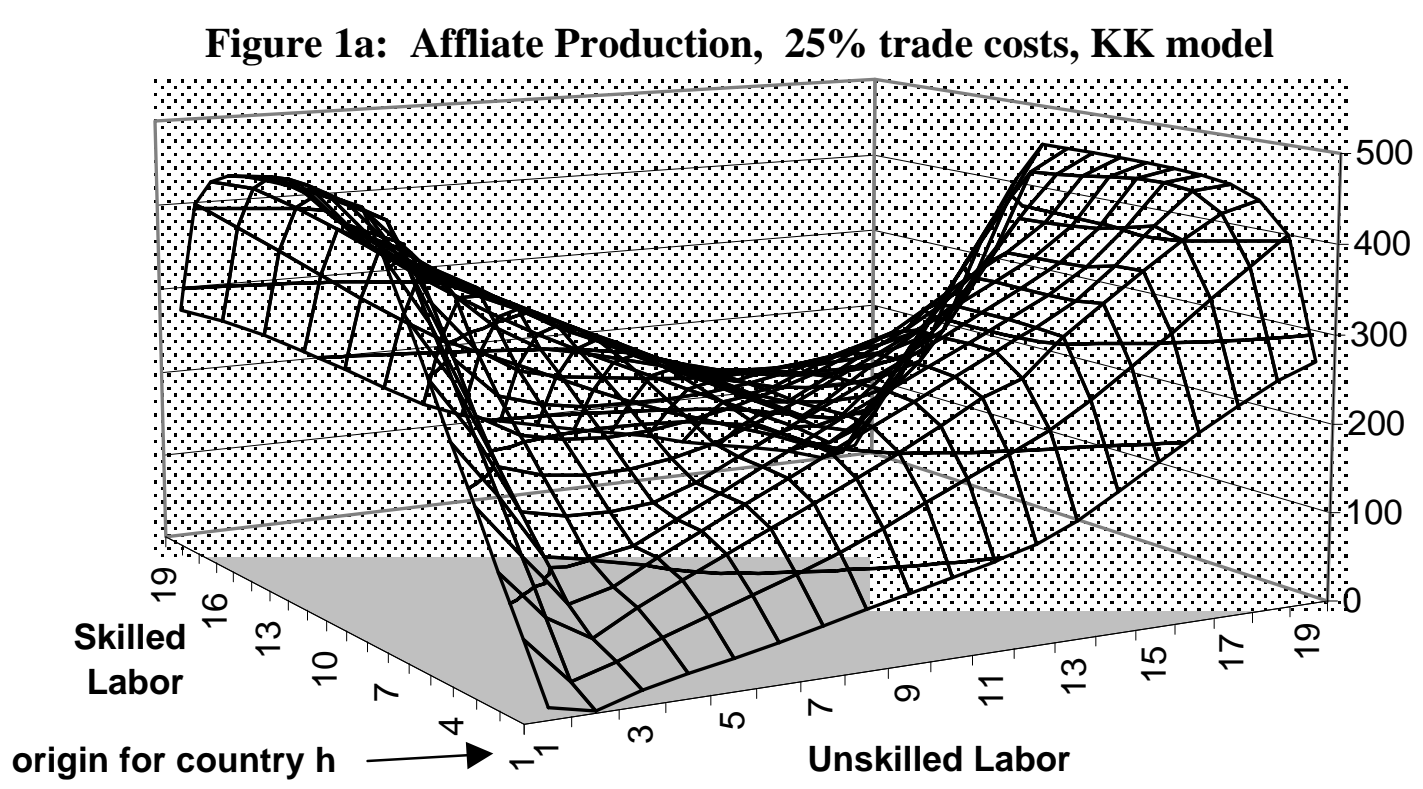

Figure 1b: Affiliate Production, 25\% Trade Costs, VER model

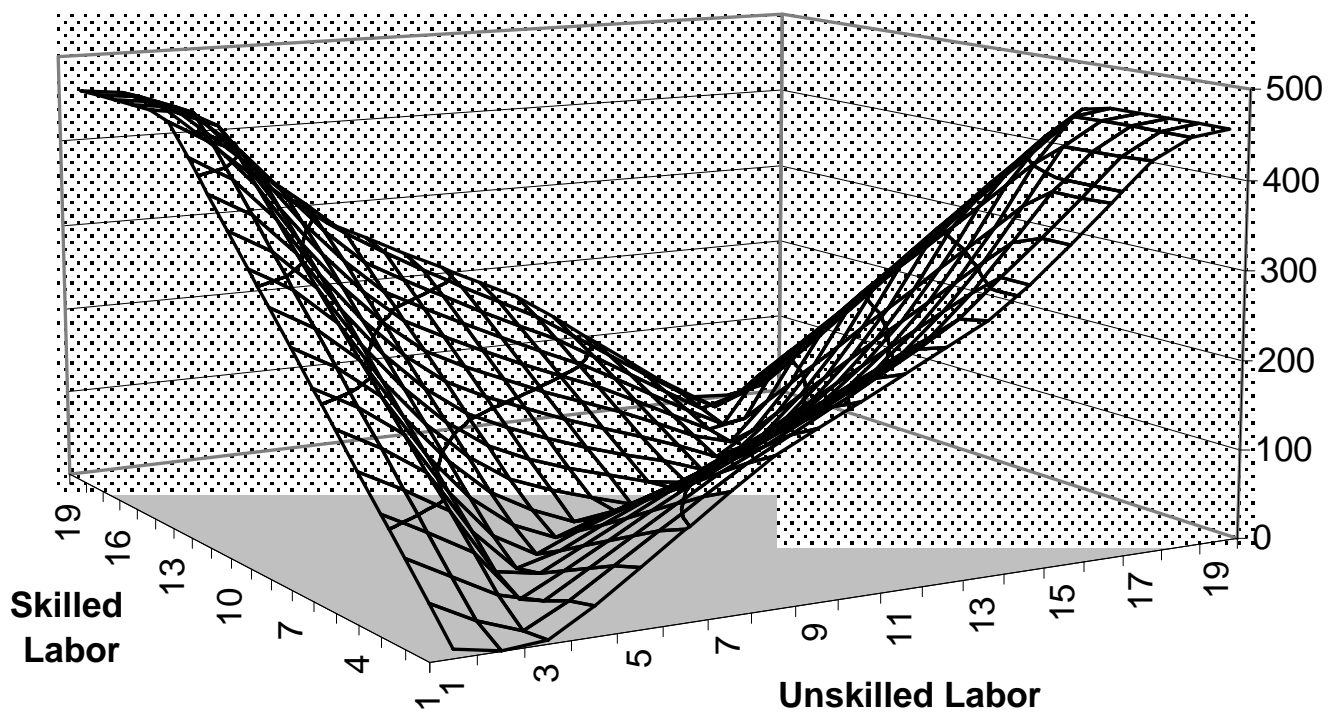

Figure 1c: Affilliate Production, 25\% Trade Costs, HOR model

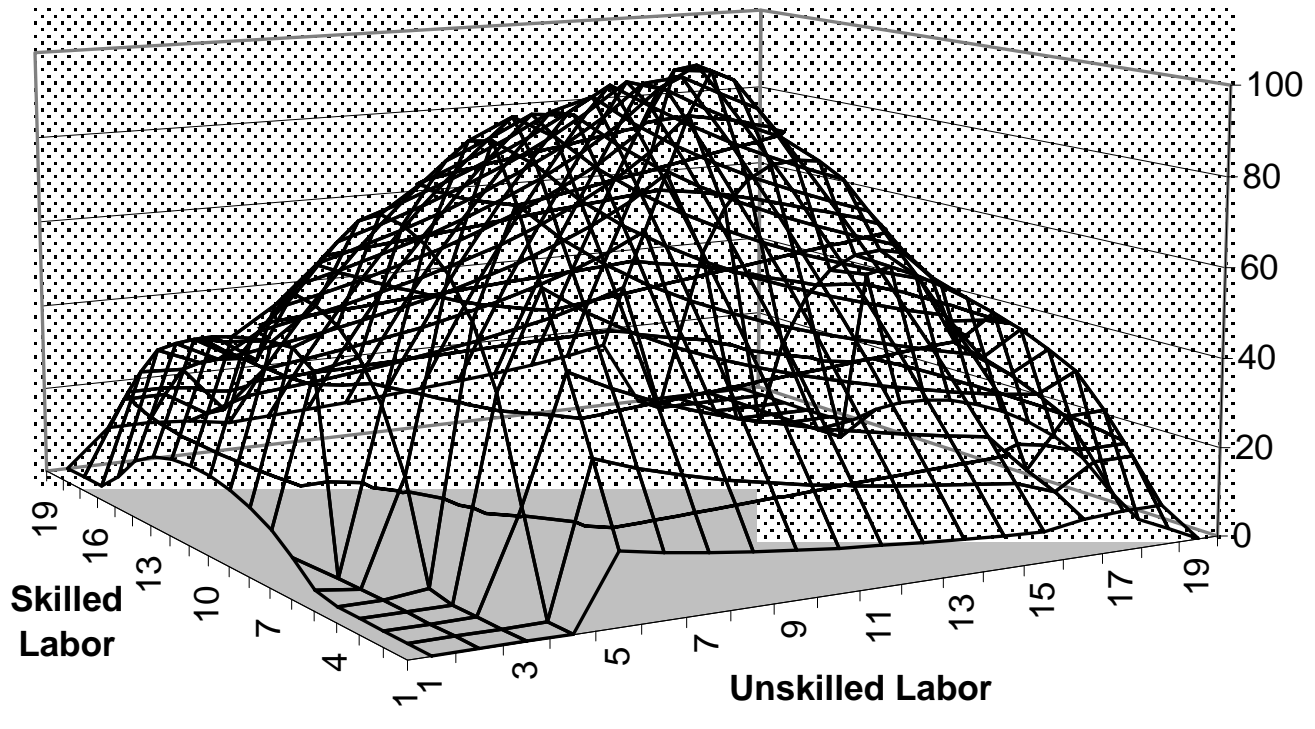


Figure 2a: Affiliate production by h-owned plants in $\mathrm{f}$ : KK model

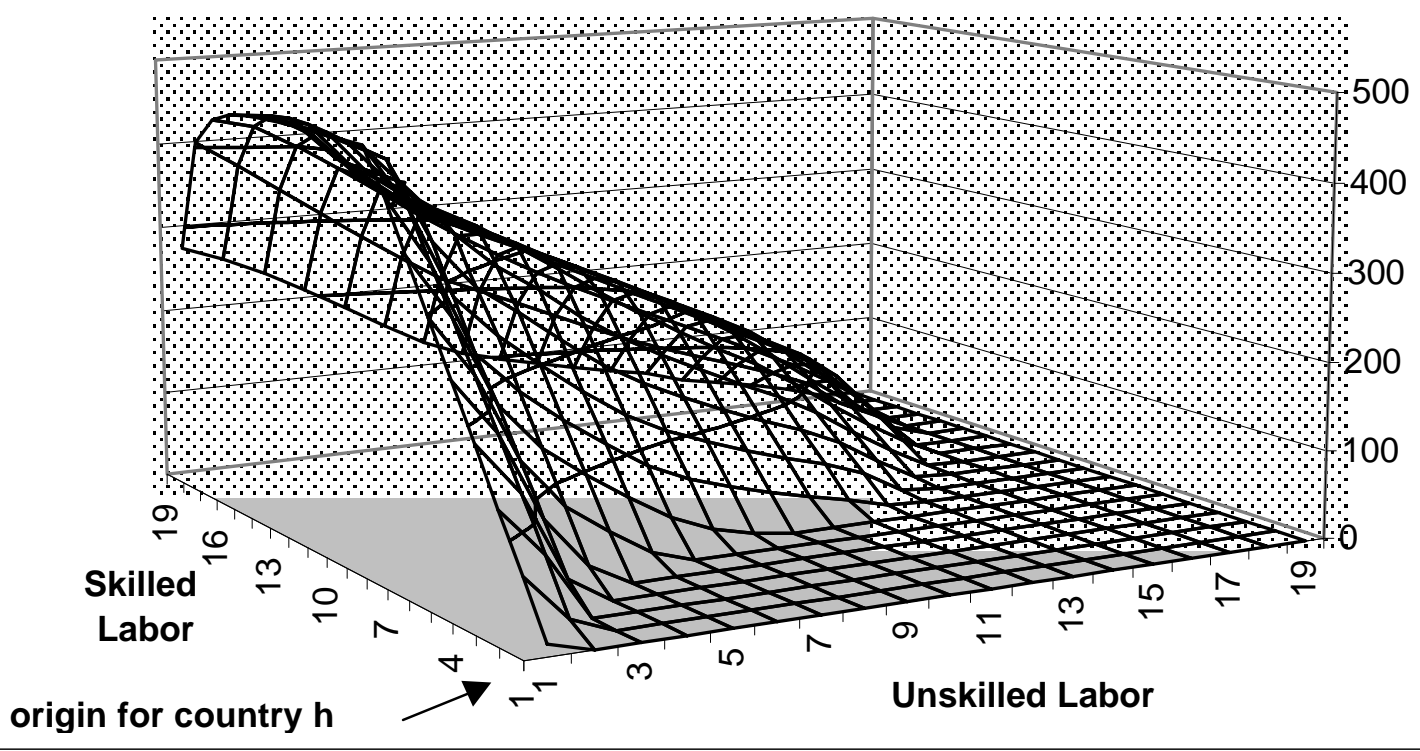

Figure 2b: Affiliate production by h-owned plants in f: VER model

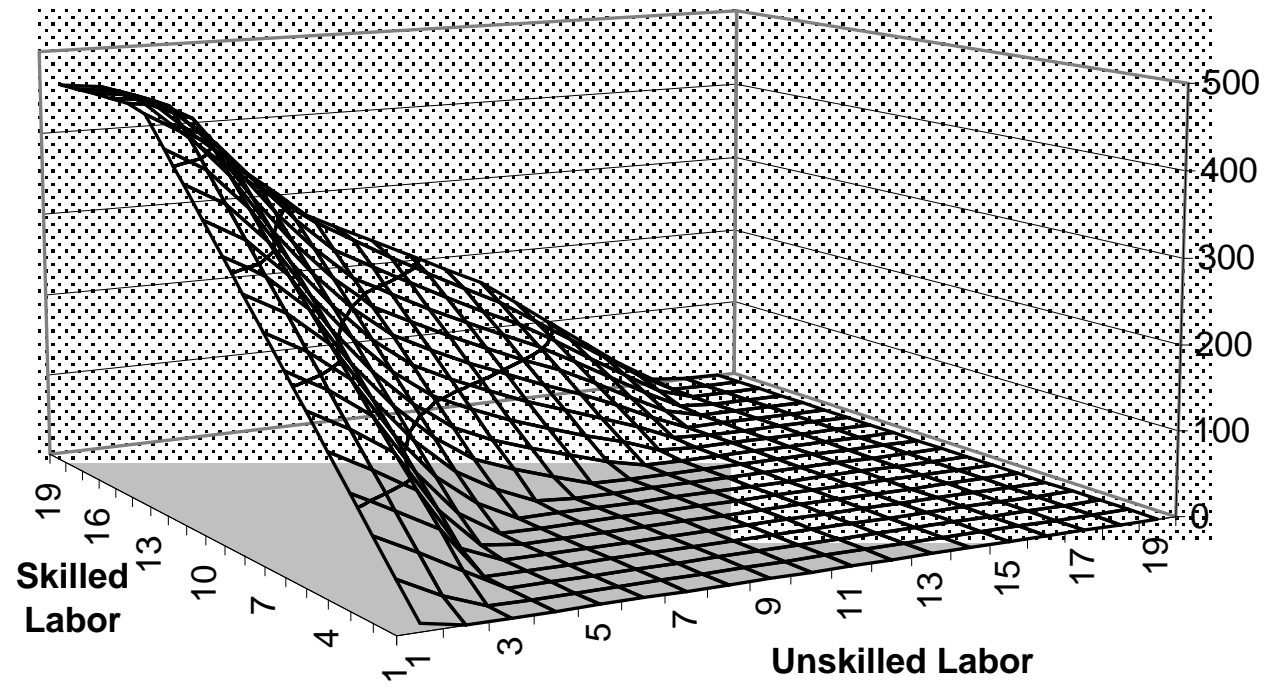

Figure 2c: Affiliate production of h-owned plants in f: HOR model

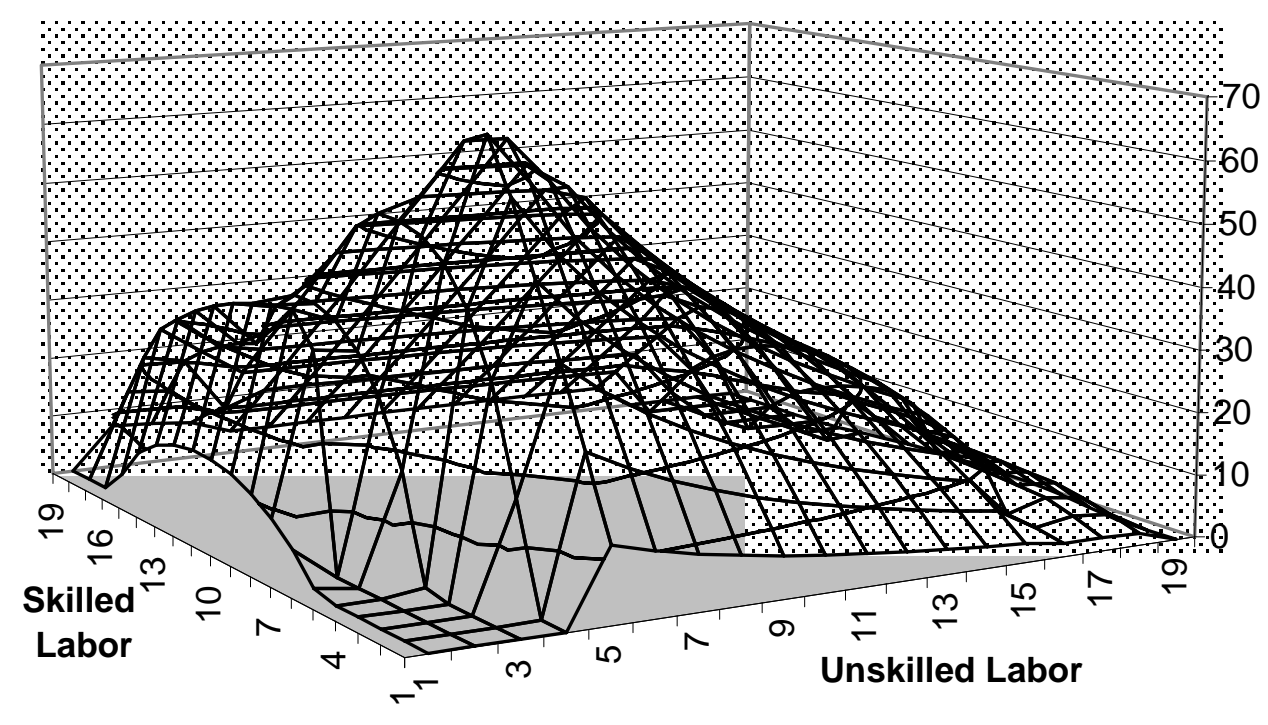


Table 1. Theoretical Predictions for Three Models $(i=$ parent, $j=$ host $)$

$\begin{array}{lccc}\text { Variable } & \text { KK } & \text { HOR } & \text { VER } \\ \text { SUMGDP } & + & + & 0 \\ \text { GDPDIFSQ } & - & - & 0 \\ \text { D2*SKDGDPD } & - & 0 & 0 \\ \text { D2*SKDSUMG } & + & - & + \\ \text { D1*SKDSUMG } & 0 & - & 0\end{array}$

\begin{tabular}{llll}
\hline DISTANCE & $?$ & $?$ & $?$ \\
INVCJ & - & - & - \\
TCJ & + & + & + \\
TCI & - & - & - \\
\hline
\end{tabular}

SUMGDP

GDPDIFF

SKDGDPD

SKDSUMG

D1

D2

$$
\begin{aligned}
& =G D_{i}+G D P_{j} \\
& =\left(G P_{i}-G D P_{j}\right) \quad \text { GDPDIFSQ }=\left(G P_{i}-G D P\right. \\
& =\text { SKDIFF*SUMGDP }=\left(S^{*} K_{i}-S_{j}\right)^{*} \text { SUMGDP } \\
& =-1 \text { if SKDIFF }=S K_{i}-S K_{j}<0 \\
& =0 \text { if SKDIFF }=S_{K_{i}}-S_{\mathbf{j}}>0 \\
& =1 \text { if SKDIFF }=S K_{i}-S K_{j}>0 \\
& =0 \text { if SKDIFF }=S_{K_{i}}-S K_{j}<0
\end{aligned}
$$$$
=\text { SKDIFF*GDPDIFF }=\left(S_{K_{i}}-S_{\mathbf{j}}\right)^{*} \text { GDPDIFF }
$$

D2 is non-zero if the parent country is skilled-labor abundant, D1 is non-zero if the host country is skilled-labor abundant 
Table 2. WLS Estimation Excluding Investment and Trade Costs (509 obs)

Variable

UNREST

KK

HOR

VER

SUMGDP

16.24
$(0.0001)$

14.52
$(0.0001)$
Yes

16.21

(0.0001)

Yes

GDPDIFSQ

$-0.001$

$-0.001$

$-0.001$

$(0.0001)$

(0.0001)

Yes

(0.0001)

Yes

D2SKDGDPD

1.19

(0.72)

D2SKDSUMG

$-8.98$

(0.008)

$-2.71$

(0.41)

No
(0.98)

No

D1SKDSUMG

$-13.23$

$(0.0001)$

(0.0001)

Yes

DISTANCE

$-1.05$

$(0.0001)$

$-1.32$

(0.0001)

?

$-22560$

$-29762$

(0.005)

(0.0001)

?

$-1.84$

(0.0001)

(0.04)

0.60

0.58

0.60

0.35

55.4

$-0.65$

150.9

Critical F 99\%

6.65

6.65

3.34

Notes: Marginal significance levels are in parentheses; "Yes" and "No" indicate conformity to predictions. 
Table 3. Tobit Estimation Excluding Investment and Trade Costs (722 obs)

Variable

SUMGDP

GDPDIFSQ

$-0.001$

$(0.0001)$

D2SKDGDPD

6.76

(0.06)

$-0.001$

(0.0001)

Yes

(0.0001)

Yes

HOR

VER

(0.0001)

Yes

$-0.001$

(0.0001)

Yes

D2SKDSUMG

$-17.96$

$(0.0001)$

$-27.82$

(0.0001)
3.23

(0.40)

No

D1SKDSUMG
0.46
(0.90)
Yes

$-11.97$

(0.0001)

Yes
5.09

(0.02)

Yes

DISTANCE

$-0.93$

$(0.0001)$

$-1.44$

(0.0001)

?

$-56105$

$(0.0001)$
$-44847$

(0.0001)
$-0.91$

(0.0001)

?

(0.0001)

Yes
INTERCEPT

Log-Likelihood

LR Test

Critical Chisq
$-6258$
$-55205$

(0.0001)
$-1.58$

(0.0001)

Notes: Marginal significance levels are in parentheses; "Yes" and "No" indicate conformity to predictions. 
Table 4. WLS Estimation Including Investment and Trade Costs (509 obs)

Variable UNREST

KK

HOR

VER

SUMGDP

15.04
$(0.0001)$

13.41

15.01

GDPDIFSQ

(0.0001)

Yes

(0.0001)

Yes

$-0.001$

$-0.001$

$-0.001$

(0.0001)

(0.0001)

Yes

(0.0001)

Yes

D2SKDGDPD

5.39

4.49

(0.12)

(0.20)

No

D2SKDSUMG

$-6.85$

$-0.93$

$-2.94$

(0.78)

(0.21)

No

Yes

3.79

(0.16)

Yes

D1SKDSUMG

$-12.83$

$-12.53$

(0.0001)

(0.0001)

Yes

DISTANCE

$-1.31$

$-1.55$

(0.0001)

(0.0001)

$-1.23$

(0.0001)

?

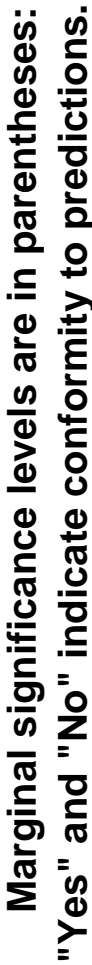

INVCJ

$$
-436.6
$$

$-442.9$

$-367.9$

$-639.3$

(0.005)

(0.0006)

Yes

(0.002)

Yes

(0.0001)

Yes

TCJ

$$
173.9
$$

169.8

(0.04)

Yes

149.9

321.6

(0.03)

(0.05)

(0.001)

Yes

Yes

TCI

-90.69
$(0.26)$

$-169.8$

$-85.7$

$-85.2$

(0.04)

Yes

(0.29)

Yes

(0.40)

Yes

INTERCEPT

$-7597$

2549

$-10592$

43337

(0.55)

(0.84)

(0.40)

(0.0001)

Adjusted R2

0.61

0.59

43.04

0.61

0.37

6.65

6.60

87.41

Critical F 99\%

6.65

3.34 
Table 5. Tobit Estimation Including Investment and Trade Costs (628 obs)

\begin{tabular}{|c|c|c|c|c|}
\hline Variable & UNREST & KK & HOR & VER \\
\hline SUMGDP & $\begin{array}{r}17.4 \\
(0.0001)\end{array}$ & $\begin{array}{r}14.28 \\
(0.0001) \\
\text { Yes }\end{array}$ & $\begin{array}{r}17.23 \\
(0.0001) \\
\text { Yes }\end{array}$ & \\
\hline GDPDIFSQ & $\begin{array}{r}-0.001 \\
(0.0001)\end{array}$ & $\begin{array}{r}-0.001 \\
(0.0001) \\
\text { Yes }\end{array}$ & $\begin{array}{r}-0.001 \\
(0.0001) \\
\text { Yes }\end{array}$ & \\
\hline D2SKDGDPD & $\begin{array}{r}11.83 \\
(0.003)\end{array}$ & $\begin{array}{r}8.56 \\
(0.04) \\
\text { No }\end{array}$ & & \\
\hline D2SKDSUMG & $\begin{array}{r}-15.05 \\
(0.0001)\end{array}$ & $\begin{array}{r}-0.52 \\
(0.89) \\
\text { No }\end{array}$ & $\begin{array}{r}-6.93 \\
(0.001) \\
\text { Yes }\end{array}$ & $\begin{array}{r}13.17 \\
(0.0001) \\
\text { Yes }\end{array}$ \\
\hline D1SKDSUMG & $\begin{array}{r}-24.51 \\
(0.0001)\end{array}$ & & $\begin{array}{r}-23.97 \\
(0.0001) \\
\text { Yes }\end{array}$ & \\
\hline DISTANCE & $\begin{array}{r}-1.48 \\
(0.0001)\end{array}$ & $\begin{array}{r}-2.01 \\
(0.0001) \\
?\end{array}$ & $\begin{array}{r}-1.36 \\
(0.0001) \\
?\end{array}$ & $\begin{array}{r}-2.63 \\
(0.0001) \\
?\end{array}$ \\
\hline INVCJ & $\begin{array}{l}-386.9 \\
(0.008)\end{array}$ & $\begin{array}{r}-280.4 \\
(0.07) \\
\text { Yes }\end{array}$ & $\begin{array}{r}-227.2 \\
(0.09) \\
\text { Yes }\end{array}$ & $\begin{array}{r}-616.3 \\
(0.0004) \\
\text { Yes }\end{array}$ \\
\hline TCJ & $\begin{array}{l}134.1 \\
(0.15)\end{array}$ & $\begin{array}{r}61.5 \\
(0.53) \\
\text { Yes }\end{array}$ & $\begin{array}{r}76.3 \\
(0.40) \\
\text { Yes }\end{array}$ & $\begin{array}{r}261.2 \\
(0.03) \\
\text { Yes }\end{array}$ \\
\hline $\mathrm{TCl}$ & $\begin{array}{r}-136.7 \\
(0.10)\end{array}$ & $\begin{array}{r}-321.1 \\
(0.0001) \\
\text { Yes }\end{array}$ & $\begin{array}{r}-125.1 \\
(0.13) \\
\text { Yes }\end{array}$ & $\begin{array}{r}-243.4 \\
(0.02) \\
\text { Yes }\end{array}$ \\
\hline INTERCEPT & $\begin{array}{r}-26271 \\
(0.07)\end{array}$ & $\begin{array}{c}-6724 \\
(0.65)\end{array}$ & $\begin{array}{r}-32791 \\
(0.02)\end{array}$ & $\begin{array}{r}46477 \\
(0.0001)\end{array}$ \\
\hline $\begin{array}{l}\text { Log-Likelihood } \\
\text { LR Test } \\
\text { Critical Chisq }\end{array}$ & -5747 & $\begin{array}{r}-5801 \\
108.0 \\
7.88\end{array}$ & $\begin{array}{r}-5751 \\
8.0 \\
7.88\end{array}$ & $\begin{array}{l}-5933 \\
372.0 \\
14.86\end{array}$ \\
\hline
\end{tabular}

